\title{
The Significance of Molecular Biomarkers on Clinical Survival Outcome Differs Depending on Colon Cancer Sidedness
}

\author{
SHO HIRABAYASHI ${ }^{1}$, MASAMICHI HAYASHI ${ }^{1}$, GORO NAKAYAMA ${ }^{1}$, SHINJI MII ${ }^{2}$, NORIFUMI HATTORI ${ }^{1}$, \\ HIROSHI TANABE ${ }^{1}$, MITSURO KANDA ${ }^{1}$, CHIE TANAKA $^{1}$, DAISUKE KOBAYASHI ${ }^{1}$, SUGURU YAMADA $^{1}$, \\ MASAHIKO KOIKE ${ }^{1}$, MICHITAKA FUJIWARA ${ }^{1}$, MASAHIDE TAKAHASHI ${ }^{2}$ and YASUHIRO KODERA ${ }^{1}$ \\ ${ }^{1}$ Department of Gastroenterological Surgery, Nagoya University Graduate School of Medicine, Nagoya, Japan; \\ ${ }^{2}$ Department of Pathology, Nagoya University Graduate School of Medicine, Nagoya, Japan
}

\begin{abstract}
Background/Aim: This retrospective study focused on the correlation between molecular markers and prognostic outcomes of colon cancer patients depending on sidedness. Materials and Methods: A total of 117 stage I-III colon cancer patients who underwent colectomy were enrolled. Novel methylation markers (KIF1A, PAX5 and $V G F)$ were selected for epigenetic evaluation and p53 and ERCC1 protein expression was examined for the investigation of genetic alterations. Results: High frequency of methylation was observed in $68.2 \%$ of right-sided and $39.7 \%$ of left-sided colon cancer cases ( $p=0.004)$. Abnormal p53 was identified in $52.3 \%$ of right-sided and $75.3 \%$ of leftsided cases $(p=0.015)$. In right-sided cases, highly methylated genes demonstrated significantly favorable disease-free survival $(p=0.049)$. Regarding left-sided cases, advanced $T$ stage $(p=0.028)$ and abnormal $p 53(p=0.028)$ were revealed to be significant predictive factors of the disease-free survival outcome. Conclusion: Molecular alterations, as significant prognostic factors, might differ depending on the sidedness of colon cancers.
\end{abstract}

Colorectal cancer (CRC) is the third most commonly diagnosed malignancy and the fourth leading cause of cancer deaths in men and women worldwide (1). Generally, CRC incidence and mortality rates remain at the highest level in countries with a high or very high human development index, such as Australia, France, Iceland, New Zealand, United States, and Japan (2). Statistics show that CRC is increasing due to the intake of red or processed meat (3), obesity (4), and alcohol consumption (5). Especially for

Correspondence to: Masamichi Hayashi, Department of Gastroenterological Surgery, Nagoya University Graduate School of Medicine, 65 Tsurumai-cho, Showa-ku, Nagoya, 466-8550, Japan. Tel: +81527442249, e-mail: m-hayashi@med.nagoya-u.ac.jp

Key Words: Methylation, p53, prognosis, sidedness, colon cancer. advanced cases, multimodal treatment strategies should be adequately selected. For further development and improvement of tailored medicine, molecular prognostic markers are required in clinical practice.

Recently, molecular differences dependent on sidedness have been intensively examined. The $\mathrm{CpG}$ island methylator phenotype (CIMP) typically frequently occurs in the rightsided colon cancers of aged females (6) and is associated with BRAF mutations (7-9). Cohen et al. observed methylation of CACAIG, IGF2, NEUROG1, RUNX3 and SOCS1 in right-sided CRCs that were closely associated with $B R A F$ mutations (10). Cao et al. reported that left-sided CRCs had a higher rate of p53-positive expression (11). According to Wang et al. (12), the abnormal p53 expression was an unfavorable prognostic predictor in CRC patients. To examine the prognostic molecular markers of colon cancer, we also have to focus on chemotherapy-associated markers including ERCC1, which is reported to be correlated with oxaliplatin resistance (13).

Though several researchers have reported disparities in molecular features according to location $(10,14)$, prognostic significance dependent on sidedness has been rarely discussed. In this research, we aimed to examine how several methylation and mutation markers impact on the prognosis of postoperative colon cancer patients and to establish prognostic factors of recurrence-free survival according to sidedness.

\section{Materials and Methods}

Sample collection. Colorectal cancer patients who underwent surgery with adequate lymphadenectomy at Nagoya University Hospital (Nagoya, Japan) between March 2008 and September 2013 were included. Cancers located in the transverse colon, rectum, and anal canal were excluded to define the sidedness of colon cancers clearly (15). Stage IV cases were also excluded due to the inconsistency in the perioperative chemotherapy given. Finally, 117 cases of stage I-III colon cancer cases were selected according to the TNM (tumor, nodes and metastases) classification $7^{\text {th }}$ Edition 
(Union for International Cancer Control) at the time of surgery. Patients' characteristics were retrospectively collected from medical records and summarized in Table I. This study was performed according to the Helsinki Declaration and the protocol was accepted by the Review Board of Nagoya University. Written informed consent for the experimental usage of surgical samples was obtained from all patients.

DNA extraction and bisulfite treatment. DNA extraction was performed using the QIAamp DNA Mini Kit (Qiagen, Hilden, Germany). The presence of $>70 \%$ of cancer cells in all tumor samples was histologically confirmed in slides taken before and after sample harvesting. Bisulfite treatment was conducted following the protocol of the BisulFlash DNA Modification Kit (Epigentek, Farmingdale, NY, USA) using $1 \mu \mathrm{g}$ of DNA.

Selection of novel methylation markers. Candidate genome-wide and cancer-wide promoter methylation markers were reported by Hoque et al. in 2008 (16). They identified 28 common cancer-specific methylation markers in 13 cancer types. Guerrero-Preston et al. also performed a genome-wide analysis in head and neck cancers, and reported ten important tumor suppressor genes that were inactivated by both promoter methylation and somatic mutations $(17,18)$. Based on the above results by our previous collaborators, we chose $K I F 1 A, P A X 5$, and $V G F$ genes as candidate methylation markers in colon cancer because these genes were methylated in various cancer types and no previous reports showed frequent methylation in colon cancer. For each gene, the chromosomal locations, functions, and methylation frequencies of various cancer types are described in Table II.

Quantitative methylation-specific PCR (QMSP). StepOnePlus (Thermo Fisher Scientific, Waltham, MA, USA) was used to perform QMSP in triplicate. The final reaction volume was $10 \mu \mathrm{l}$, which contained $600 \mathrm{nmol}$ forward and reverse primers, $200 \mathrm{nmol} / \mathrm{l}$ probe, 0.6 unit Platinum Taq DNA Polymerase (Thermo Fisher Scientific), dATP, dCTP, dGTP, and dTTP in a concentration of $200 \mu \mathrm{mol}$ each, $6.7 \mathrm{mmol} / \mathrm{l} \mathrm{MgCl}_{2}$, and $1.5 \mu \mathrm{l}$ bisulfite-modified DNA. The PCR settings were as follows: initial denaturation at $95^{\circ} \mathrm{C}$ for $10 \mathrm{~min}$ followed by 40 cycles of $95^{\circ} \mathrm{C}$ for $3 \mathrm{sec}$ and $60^{\circ} \mathrm{C}$ for $10 \mathrm{sec}$. Bisulfite-Converted Universal Methylated Human DNA Standard (Zymo Research, Irvine, CA, USA) to construct the standard curve and ultrapure water as a positive control were added to each plate. Mean values were calculated from triplicate samples and used for analyses. The QMSP value is expressed as the percentage of fluorescence intensity for the PCR products of the target gene compared with that of $A C T B$ (reference gene), multiplied by 100 for easier tabulation. The oligonucleotide sequences of the primers and probes are described in Table III. All primers and probes were from Hokkaido System Science (Sapporo, Japan).

Immunohistochemical staining (IHC). Formalin-fixed paraffinembedded tumor tissues were sliced ( $4 \mu \mathrm{m}$ each) and used to validate the expression levels of p53 and ERCC1 proteins. An additional slide without a monoclonal antibody was used as a negative control. Slides were deparaffinized in xylene and rehydration was performed through $100 \%$ ethanol for $5 \mathrm{~min}$, three times. Endogenous peroxidase activity was blocked with $3 \% \mathrm{H}_{2} \mathrm{O}_{2}$. For antigen retrieval, heat-induced epitope retrieval was conducted by 10 -min boiling in Tris-EDTA buffer $\mathrm{pH}$ 8.0. The sections were incubated for one $\mathrm{h}$ at room
Table I. Clinicohistological characteristics of 117 colon cancer cases.

\begin{tabular}{llc}
\hline Characteristics & & Number of cases (\%) \\
\hline Age & $<70$ & $58(49.6)$ \\
& $\geq 70$ & $59(50.4)$ \\
Gender & Female & $70(59.8)$ \\
& Male & $47(40.2)$ \\
Sidedness & Right & $44(37.6)$ \\
& Left & $73(62.4)$ \\
Differentiation & Well, Moderately & $111(94.9)$ \\
& Poorly, Mucinous & $6(5.1)$ \\
T stage & T1-3 & $93(79.5)$ \\
& T4 & $24(20.5)$ \\
N stage & N0 & $71(60.7)$ \\
& N1-2 & $46(39.3)$ \\
Stage & I-II & $71(60.7)$ \\
& III & $46(39.3)$ \\
Lymphatic invasion & Absent & $38(32.5)$ \\
& Present & $79(67.5)$ \\
Venous invasion & Absent & $63(53.8)$ \\
& Present & $54(46.2)$ \\
Adjuvant chemotherapy & No & $64(54.7)$ \\
& Yes & $53(45.3)$ \\
\hline
\end{tabular}

temperature with anti-p53 mouse monoclonal antibody (1:50; Santa Cruz Biotechnology, Dallas, TX, USA) or anti-ERCC1 rabbit monoclonal antibody (1:50; Cell Signaling Technology, Danvers, MA, USA). The secondary antibody (Dako EnVision and System-HRP Labelled Polymer, Agilent, Santa Clara, CA, USA) was used for 30 $\min$ at room temperature followed by incubation in 3,3'diaminobenzidine for $2.5 \mathrm{~min}$ for $\mathrm{p} 53$ and $10 \mathrm{~min}$ for ERCC1, and then hematoxylin counterstaining was applied for $15 \mathrm{~min}$. Slides were dehydrated in $70 \%, 80 \%, 90 \%$, and $100 \%$ ethanol followed by two changes of xylene and then mounted.

For the evaluation of $\mathrm{p} 53$, we defined the weak expression as normal and absent, or strong expression as abnormal according to McGregor et al. (19). In detail, samples were classified into four grades according to the percentage of p53-positive cells (Figure 1). Scores 0 and 3 were regarded as aberrant expression, while scores 1 and 2 were normal expression. The percentage of ERCC1-positive cells was also categorized into four grades (Figure 2). Scores 0 and 1 were defined as normal, and scores 2 and 3 were defined as strong staining. Slides were analyzed independently by two cancer pathologists without any information about tumor sidedness and survival outcomes.

Statistical analysis. The Mann-Whitney $U$-test was performed to evaluate the differences in continuous variables, whereas the Fisher's exact test was used for categorical valuables. The Cox proportional hazards model was used for univariable and multivariable analyses. Disease-free survival (DFS) was defined as the time from surgery to the time of first documentation of any disease recurrence. Survival curves were drawn using the KaplanMeier method, and the difference was calculated by log-rank test. Two-sided $p$-values less than 0.05 were considered statistically significant. All statistical analyses including receiver operating characteristic (ROC) curves were performed using JMP version 14.0.0 (SAS Institute Inc., Cary, NC, USA). 
Table II. Details of selected novel methylation markers.

\begin{tabular}{|c|c|c|c|c|c|c|}
\hline Gene & \multicolumn{2}{|c|}{ KIF $1 A$} & \multicolumn{2}{|c|}{ PAX5 } & \multicolumn{2}{|c|}{$V G F$} \\
\hline Location on chromosomes & \multicolumn{2}{|c|}{$2 q 37.7$} & \multicolumn{2}{|c|}{$9 \mathrm{p} 13.2$} & \multicolumn{2}{|c|}{$7 \mathrm{q} 22.1$} \\
\hline Protein function & \multicolumn{2}{|c|}{$\begin{array}{l}\text { Transporter of membranous } \\
\text { organelles along } \\
\text { axonal microtubules }\end{array}$} & \multicolumn{2}{|c|}{$\begin{array}{c}\text { Activator of B cell differentiation, } \\
\text { neural development, } \\
\text { and spermatogenesis }\end{array}$} & \multicolumn{2}{|c|}{$\begin{array}{l}\text { Expressed in neuroendocrine } \\
\text { cells and up-regulated } \\
\text { by nerve growth factor }\end{array}$} \\
\hline \multirow{2}{*}{$\begin{array}{l}\text { Methylation frequencies } \\
\text { in cancer cell lines }\end{array}$} & HNSCC & $2 / 3(67 \%)$ & $\mathrm{HCC}$ & $8 / 12(67 \%)$ & Bladder cancer & $4 / 7(57 \%)$ \\
\hline & Breast cancer & $8 / 9(89 \%)$ & $\begin{array}{c}\text { Esophageal cancer } \\
\text { Gastric cancer }\end{array}$ & $\begin{array}{l}8 / 9(89 \%) \\
7 / 8(88 \%)\end{array}$ & Ovarian cancer & $2 / 7(29 \%)$ \\
\hline
\end{tabular}

HNSCC: Head and neck squamous cell carcinoma; HCC: hepatocellular carcinoma.

Table III. List of primers and probes used for QMSP.

\begin{tabular}{|c|c|c|c|c|c|}
\hline Gene & Forward 5'-3' (primer) & Probe & Reverse 5'-3' (primer) & Temperature & Amplicon \\
\hline \multirow[t]{2}{*}{$A C T B$} & TGGTGATGGAGGAGG & (FAM-5', 3'-TAMRA) ACCACCAC & AАCCAATAAAАCCTA & $60^{\circ} \mathrm{C}$ & $133 \mathrm{bp}$ \\
\hline & TTTAGTAAGT & CCAACACACAATAACAAACACA & СТССТСССТТАА & & \\
\hline \multirow[t]{2}{*}{ KIF1A } & GCGCGATAAATTAGTT & (FAM-5', 3'-BHQ) CCTCCCGAAA & CTCGACGACTACTCT & $60^{\circ} \mathrm{C}$ & $140 \mathrm{bp}$ \\
\hline & GGCGATT & CGCTAATTAACTACGCG & ACGCTAT & & \\
\hline \multirow[t]{2}{*}{ PAX5 } & GCGTAAGAGAGACGA & (FAM-5', 3'-TAMRA) AGAGGTTC & ATATTCGCGAACACC & $60^{\circ} \mathrm{C}$ & $112 \mathrm{bp}$ \\
\hline & AGGTAAG & GCGTAGTTTCGTCGG & TCTACTAC & & \\
\hline \multirow[t]{2}{*}{$V G F$} & GGATAGCGTTCGTAGG & (FAM-5', 3'-BHQ) GCGCCCAAA & AAAAACCGAATTCCC & $60^{\circ} \mathrm{C}$ & 202 bp \\
\hline & CG & AACGACGTAAACCTAAATAC & CACCCCG & & \\
\hline
\end{tabular}

QMSP: Quantitative methylation-specific PCR.

\section{Results}

Measurement of QMSP values. Tumors and adjacent normal tissues of 117 colon cancer samples were applied to QMSP assays. QMSP values of all three genes are shown in Figure 3. Methylation frequencies in tumor tissues were significantly higher than those in adjacent normal tissues in KIF1A $(p<0.001)$, PAX5 $(p<0.001)$, and VGF $(p<0.001)$. Next, we calculated the cut-off values by receiver operating characteristic (ROC) curves between QMSP values of tumors and adjacent normal tissues (Figure 4). Relatively high area under the curve values were obtained (0.721 in KIF IA, 0.916 in $P A X 5$, and 0.479 in $V G F$ ). According to the cut-off values, all cases were classified into high QMSP cases and low QMSP cases. Consequently, we divided 117 cases into 59 methylation frequency-high cases (gray color, high QMSP in 2-3 genes) and 58 methylation frequency-low cases (white color, low QMSP in 0-1 gene) (Figure 5).

Methylation frequency and clinicohistological factors. The clinicohistological backgrounds of all 117 colon cancer cases are summarized in Table I. Right-sided colon cancers derived from the midgut were found in $44(37.6 \%)$ cases, while leftsided colon cancers derived from hindgut were found in 73 cases $(62.4 \%)$. The association of these factors with methylation frequency is shown in Table IV. High frequency of methylation was significantly associated with aged patients $(p=0.010)$ and right-sided colon cancers $(p=0.004)$, while no significant association was found with tumor factors including $\mathrm{T}$ and $\mathrm{N}$ stages, and lymphatic invasion.

IHC scores of p53 and ERCC1. IHC scores of p53 and ERCC1 are shown in Table V. Abnormal expression of p53 and ERCC1 was observed in $66.7 \%$ (78 cases) and $22.2 \%$ (26 cases) of all cases, respectively. The associations of IHC abnormalities with methylation frequency and sidedness are summarized in Table VI. Abnormal expression of p53 was highly observed in left-sided colon cancers $(p=0.015)$, but did not correlate with methylation status. As for the expression of ERCC1, no correlation was observed with both methylation status and tumor sidedness.

Prognostic factors depending on sidedness. Kaplan-Meier survival curves of DFS demonstrated that a high frequency of methylation was significantly related to better prognosis in right-sided colon cancer patients $(p=0.042)$, whereas no correlation was found in left-sided colon cancers $(p=0.967)$ (Figure 6a, b). Interestingly, abnormal p53 expression 


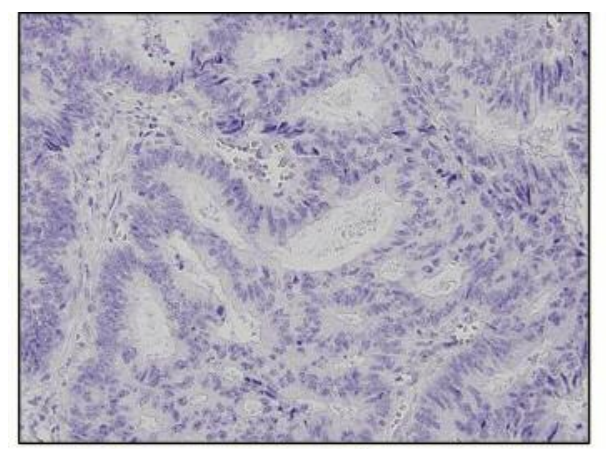

Score 0: 0\% (abnormal)

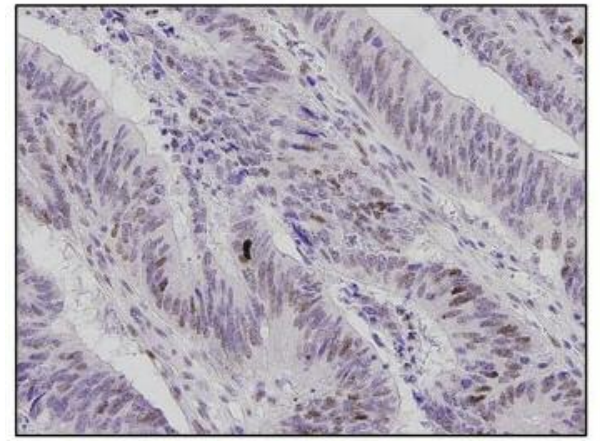

Score 2: $10-50 \%$ (normal)

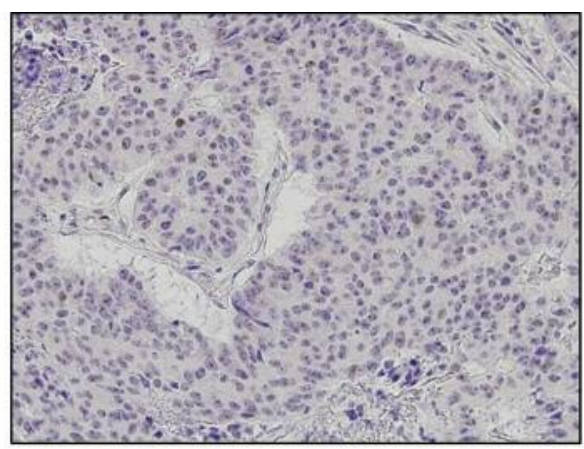

Score 1: 0-10\% (normal)

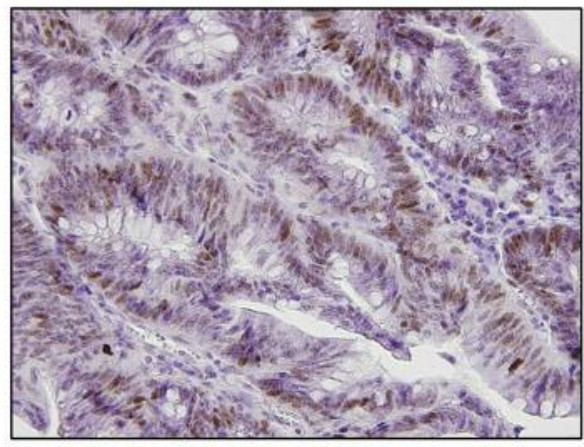

Score 3: $50-100 \%$ (abnormal)

Figure 1. Immunohistochemical staining for p53. The expression of p53 was evaluated at a $\times 200$ magnification. In accordance with the percentage of p53-positive cells, samples were categorized into four grades: score 0 (0\%), score 1 (0-10\%), score 2 (10-50\%) and score 3 (50-100\%).

showed completely opposite behaviors between right and left cases; the worse prognosis was observed in right-sided colon cancers $(p=0.034)$ and favorable prognosis was found in leftsided colon cancers $p=0.043$ ) (Figure 6c, d).

Univariable analysis of DFS was performed using the proportional hazard model for individual prognostic factors of each side (Table VII). Besides advanced $\mathrm{T}$ stage $(\mathrm{HR}=5.31 ; 95 \% \mathrm{CI}=1.31-21.48 ; p=0.019)$, high methylation frequency $\quad(\mathrm{HR}=0.25 ; 95 \% \mathrm{CI}=0.06-1.06 ; p=0.060)$ and abnormal p53 expression $(\mathrm{HR}=6.99 ; 95 \% \mathrm{CI}=0.86-56.88$; $p=0.069)$ were marginally significant prognostic factors in the right-sided colon cancers. On the other hand, in left-sided colon cancers, advanced $\mathrm{T}$ stage $(\mathrm{HR}=3.04,95 \% \mathrm{CI}=0.96-$ $9.60 ; p=0.058)$ and abnormal $\mathrm{p} 53$ expression $(\mathrm{HR}=0.33$; $95 \% \mathrm{CI}=0.11-1.02 ; p=0.055)$ were marginally significant.

In the multivariable analysis of DFS, we included all factors with $p$-values below 0.10 (Table VII). In right-sided colon cancers, high methylation frequency was statistically significant $(\mathrm{HR}=0.23 ; 95 \% \mathrm{CI}=0.05-0.99 ; p=0.049)$, while in left-sided colon cancers, advanced $\mathrm{T}$ stage $(\mathrm{HR}=3.72$; 95\% CI $=1.15-12.05 ; p=0.028)$ and abnormal $\mathrm{p} 53$ expression $(\mathrm{HR}=0.27 ; 95 \% \mathrm{CI}=0.09-0.87 ; p=0.028)$ were significant prognostic factors.

\section{Discussion}

Genome-wide hypermethylation of colon cancers is reported to be predominant in aged and female cases (6), mainly located in the right-sided colon $(6,20)$, and has a better prognosis (21). Inoue et al. (22) revealed that accumulated gene methylation in sessile serrated adenoma/polyp (SSA/P) is closely associated with the development of cancers. Also, $B R A F$ mutation is common in CIMP-positive CRC tumors (7-9). The BRAF mutation, V600E, is considered to initiate a serrated pathway that promotes the progression of normal mucosa to precancerous tissues (23). Although BRAF mutation is reported to be one of the poor prognostic factors in advanced colon cancers, it does not influence the survival outcomes among early-stage colon cancers (24).

The significance of mutated TP53 on colon cancer survival remains controversial. In this study, we examined p53 protein expression, which is reported to be more discriminative than TP53 mutation status (25). The majority of TP53 mutations are missense and have an oncogenic role by gain-of-function, while the loss of wild-type TP53 (loss-of-function) is a minor event, but also affects the tumor invasion process (26). Then, we included all mutation types into abnormal p53 cases and 


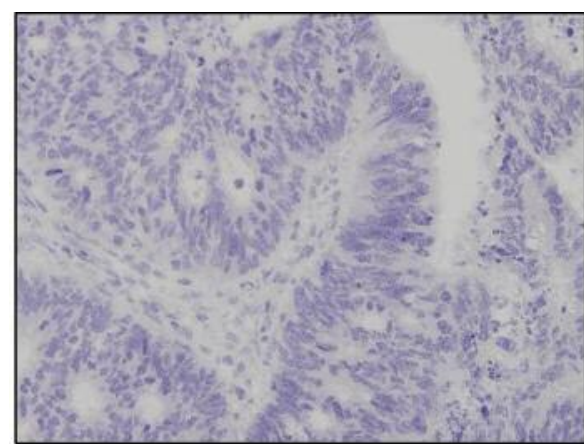

Score 0: 0\% (normal)

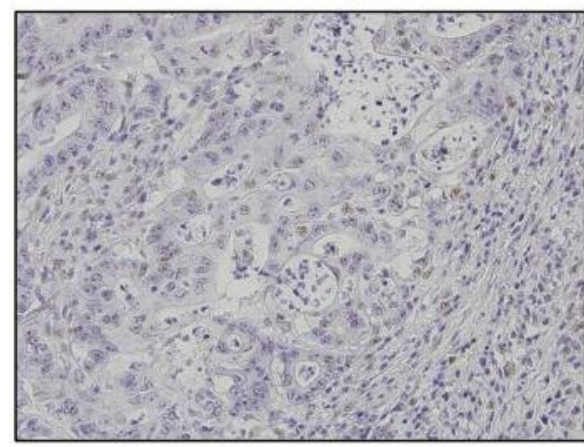

Score 2: $10-50 \%$ (abnormal)

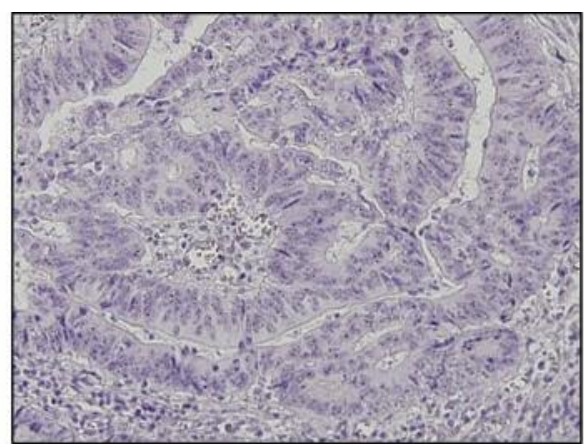

Score 1: 0-10\% (normal)

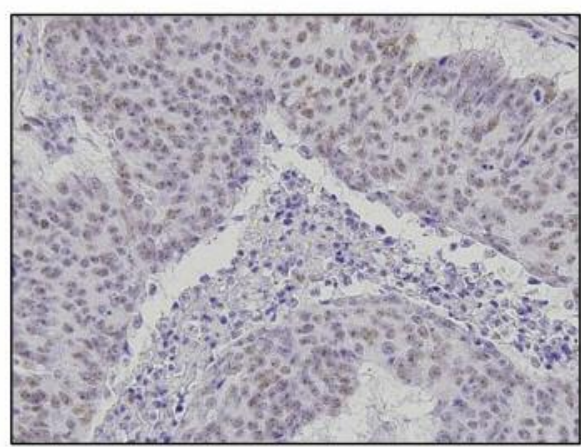

Score 3: $50-100 \%$ (abnormal)

Figure 2. Immunohistochemical staining for ERCC1. The expression of ERCC1 was validated at a $\times 200$ magnification. In accordance with the percentage of ERCC1-positive cells, samples were classified into four grades: score 0 (0\%), score 1 (0-10\%), score 2 (10-50\%) and score 3 (50$100 \%)$.

\section{a. $K I F 1 A$}

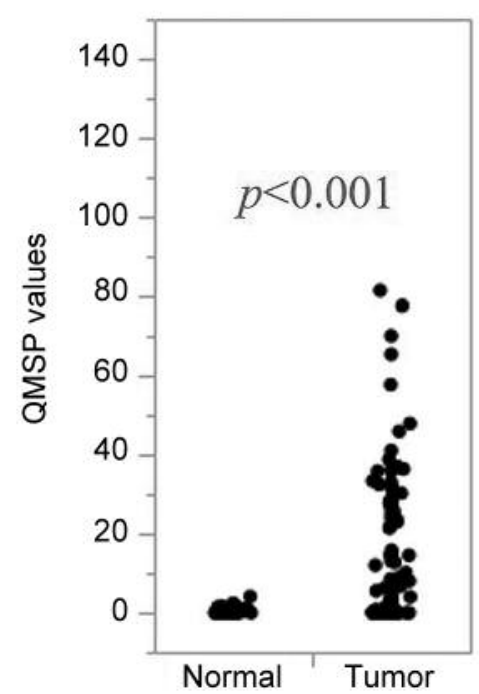

b. PAX5

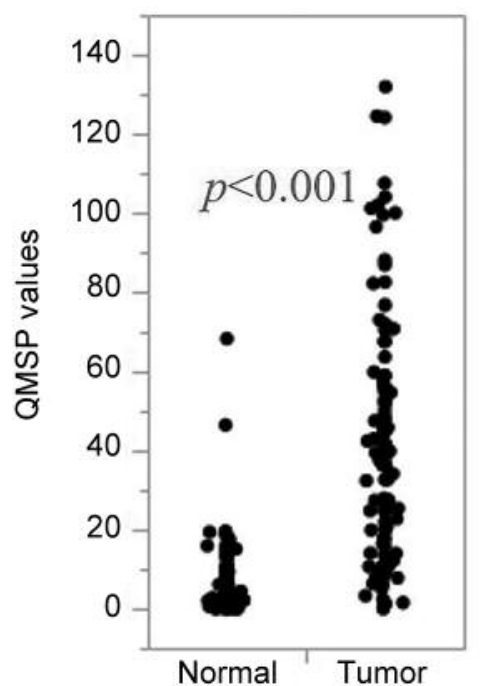

c. $V G F$

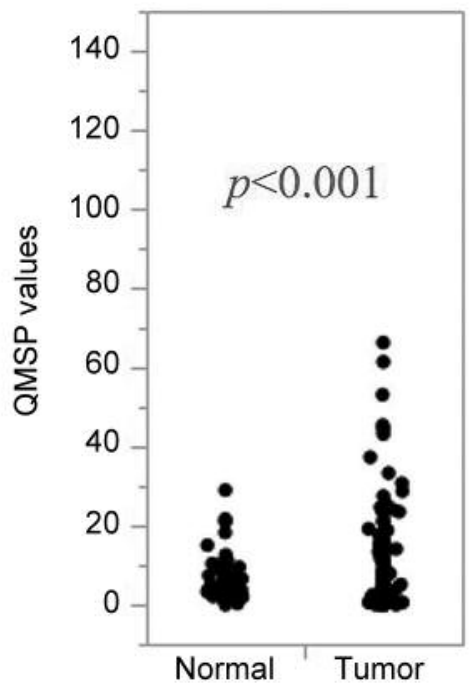

Figure 3. Quantitative methylation-specific PCR (QMSP) values of normal and tumor tissues. Results of QMSP assays in 117 colon cancer samples are shown. QMSP values of tumors were significantly higher than those of adjacent normal tissues in KIF1A $(a, p<0.001), P A X 5(b, p<0.001), a n d$ $\operatorname{VGF}(c, p<0.001)$. 
a. $K I F 1 A$

Cut-off value: 1.97

Sensitivity: $54 \%$

Specificity: $97 \%$

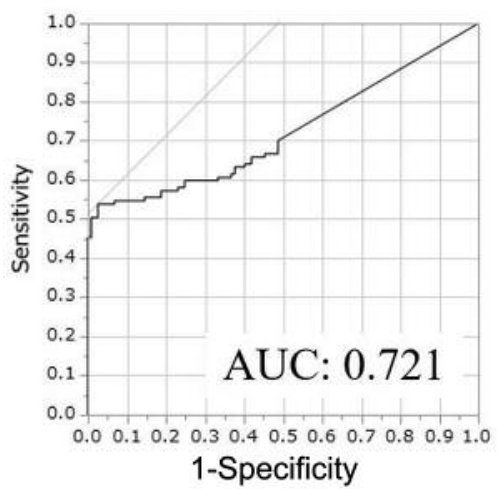

b. $P A X 5$

Cut-off value: 19.92

Sensitivity: $74 \%$

Specificity: $98 \%$

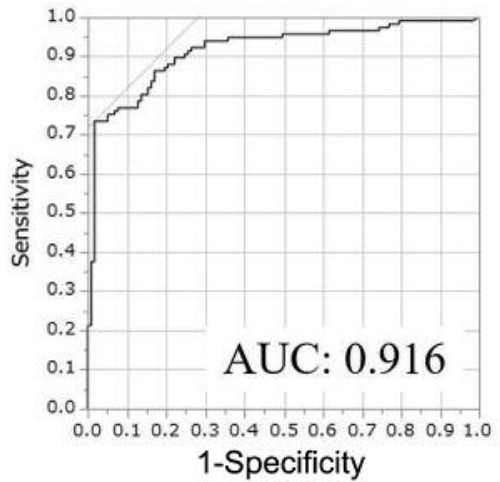

c. $V G F$

Cut-off value: 11.31

Sensitivity: $32 \%$

Specificity: $95 \%$

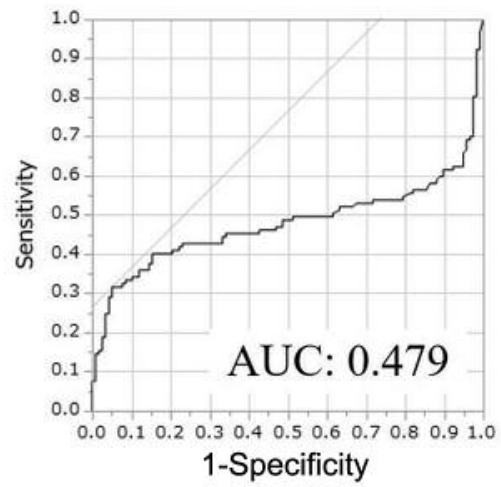

Figure 4. Receiver operation characteristic (ROC) curves. ROC curves were used to calculate the cut-off values between tumors and adjacent normal tissues.

Table IV. Association of clinicohistological characteristics with methylation frequency.

\begin{tabular}{|c|c|c|c|}
\hline \multirow[t]{2}{*}{ Characteristics } & \multicolumn{2}{|c|}{ Methylation frequency } & \multirow[t]{2}{*}{$p$-Value } \\
\hline & High (59 cases) & Low (58 cases) & \\
\hline \multicolumn{4}{|l|}{ Age group } \\
\hline$<70$ & $22(37.9 \%)$ & $36(62.1 \%)$ & 0.010 \\
\hline$\geq 70$ & $37(62.7 \%)$ & $22(37.3 \%)$ & \\
\hline \multicolumn{4}{|l|}{ Gender } \\
\hline Female & $33(47.1 \%)$ & $37(52.9 \%)$ & 0.452 \\
\hline Male & $26(55.3 \%)$ & $21(44.7 \%)$ & \\
\hline \multicolumn{4}{|l|}{ Sidedness } \\
\hline Right & $30(68.2 \%)$ & $14(31.8 \%)$ & 0.004 \\
\hline Left & $29(39.7 \%)$ & $44(60.3 \%)$ & \\
\hline \multicolumn{4}{|l|}{ Differentiation } \\
\hline Well, Moderately & $56(50.5 \%)$ & $55(49.5 \%)$ & 1.000 \\
\hline Poorly, Mucinous & $3(50.0 \%)$ & $3(50.0 \%)$ & \\
\hline \multicolumn{4}{|l|}{ T stage } \\
\hline T1-3 & $46(49.5 \%)$ & $47(50.5 \%)$ & 0.820 \\
\hline $\mathrm{T} 4$ & $13(54.2 \%)$ & $11(45.8 \%)$ & \\
\hline \multicolumn{4}{|l|}{$\mathrm{N}$ stage } \\
\hline No & $40(56.3 \%)$ & $31(43.7 \%)$ & 0.132 \\
\hline $\mathrm{N} 1-2$ & $19(41.3 \%)$ & $27(58.7 \%)$ & \\
\hline \multicolumn{4}{|l|}{ Stage } \\
\hline I-II & $40(56.3 \%)$ & $31(43.7 \%)$ & 0.132 \\
\hline III & $19(41.3 \%)$ & $27(58.7 \%)$ & \\
\hline \multicolumn{4}{|l|}{ Lymphatic invasion } \\
\hline Absent & $22(57.9 \%)$ & $16(42.1 \%)$ & 0.325 \\
\hline Present & $37(46.8 \%)$ & $42(53.2 \%)$ & \\
\hline \multicolumn{4}{|l|}{ Venous invasion } \\
\hline Absent & $36(57.1 \%)$ & $27(42.9 \%)$ & 0.140 \\
\hline Present & $23(42.6 \%)$ & $31(57.4 \%)$ & \\
\hline
\end{tabular}

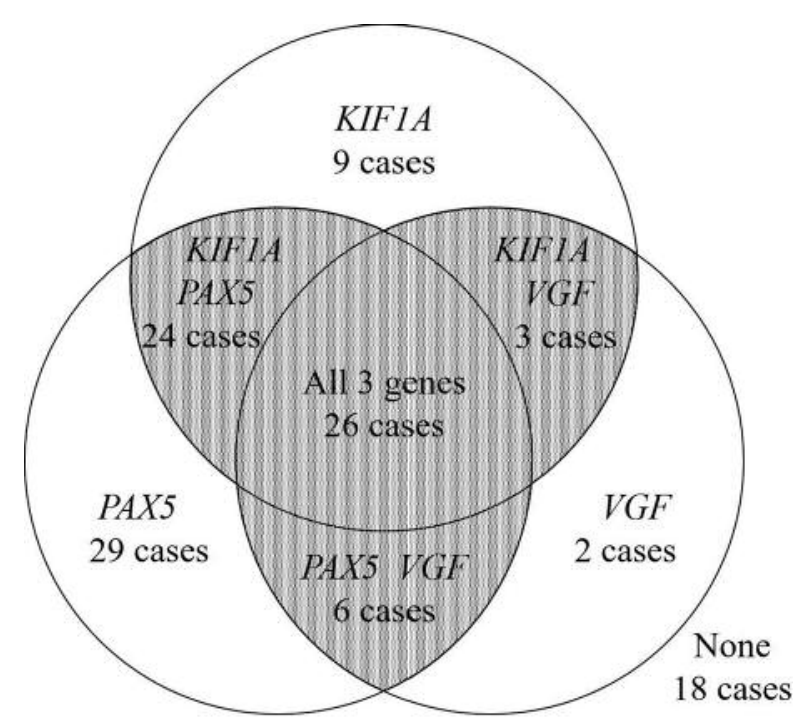

Figure 5. Distribution of cases according to methylated genes. Methylation frequency-high group (2-3 genes, gray area) included 59 cases, while 58 cases belonged to the methylation frequency-low group (0-1 gene, white area).

compared them with normal p53 cases. Previously, Paluszkiewicz et al. (27) showed that p53 abnormal accumulation was correlated with a lower survival rate of patients with left-sided CRCs. Conversely, a few reports suggested that $\mathrm{p} 53$ overexpression is a favorable prognostic factor, especially in the distal colon (28). For example, Soong et al. examined over 500 colorectal cancer cases and demonstrated that $\mathrm{p} 53$ accumulation was correlated with better 
Table V. IHC scores of p53 and ERCC.

\begin{tabular}{lccccc}
\hline & IHC scores & 0 & 1 & 2 & 3 \\
\hline p53 & Number of cases (\%) & $16(13.7)$ & $18(15.4)$ & $21(17.9)$ & Normal \\
& Definition of expression & Abnormal & Normal & Abnormal \\
ERCC1 & Number of cases (\%) & $48(41.0)$ & $43(36.8)$ & $13(11.1)$ & $13(11.1)$ \\
& Definition of expression & Normal & Normal & Abnormal & Abnormal \\
\hline
\end{tabular}

IHC: Immunohistochemical staining.

Table VI. Association of molecular markers with methylation frequency and sidedness.

\begin{tabular}{|c|c|c|c|c|c|c|c|}
\hline \multirow[t]{2}{*}{ Markers } & \multirow[t]{2}{*}{ Expression } & \multicolumn{2}{|c|}{ Methylation frequency } & \multirow[t]{2}{*}{$p$-Value } & \multicolumn{2}{|c|}{ Sidedness } & \multirow[t]{2}{*}{$p$-Value } \\
\hline & & High (59 cases) & Low (58 cases) & & Right (44 cases) & Left ( 73 cases) & \\
\hline \multirow[t]{2}{*}{ p53 } & Normal & $23(59.0 \%)$ & $16(41.0 \%)$ & \multirow[t]{2}{*}{0.240} & $21(53.8 \%)$ & $18(46.2 \%)$ & \multirow[t]{2}{*}{0.015} \\
\hline & Abnormal & $36(46.2 \%)$ & $42(53.8 \%)$ & & $23(29.5 \%)$ & $55(70.5 \%)$ & \\
\hline \multirow[t]{2}{*}{ ERCC1 } & Normal & $44(48.4 \%)$ & $47(51.6 \%)$ & \multirow[t]{2}{*}{0.506} & $31(34.1 \%)$ & $60(65.9 \%)$ & \multirow[t]{2}{*}{0.170} \\
\hline & Abnormal & $15(57.7 \%)$ & $11(42.3 \%)$ & & $13(50.0 \%)$ & $13(50.0 \%)$ & \\
\hline
\end{tabular}

prognosis in distal cancers but not proximal cancers (29). Our results are in accordance with this study; abnormal p53 expression was associated with better prognosis in left-sided colon cancers and poor prognosis in right-sided colon cancers.

Subgroup analyses of our cohort showed that advanced $\mathrm{T}$ stage, advanced $\mathrm{N}$ stage, and lymph-vascular invasionpositive cases were dominant in p53 abnormal cases on both sides. Thus, abnormal p53 cases were expected to show a poor prognosis for right-sided colon cancers (Figure 6c). However, in left-sided colon cancers, abnormal p53 cases demonstrated better survival than normal p53 cases (Figure $6 d)$. Especially among those left-sided cases who received adjuvant chemotherapy, abnormal p53 cancers indicated significantly favorable DFS than normal p53 cancers ( $p=0.003$, Figure 7$)$. In cases without adjuvant chemotherapy, we could not identify any survival difference between normal and abnormal p53 cancers on both sides. These findings imply the possibility that p53 abnormal expression-related chemosensitivity influences survival outcomes. Certainly, Zaanan et al. highlighted that sensitivity to oxaliplatin seems to be increased in p53 abnormally-overexpressing cases (30). They demonstrated that the survival of FOLFOX-treated cases had significantly better survival than 5-FU/leucovorintreated cases in p53-overexpressing cases, whereas no survival difference was found in p53 normal cases. Since p53 abnormal cases are usually dominant in left-sided colon cancers $[75.3 \%$ (55/73) in left, 52.3\% (23/44) in right, Table $\mathrm{VI}$ ] and oxaliplatin-based regimens were frequently used for advanced cases in this study as adjuvant chemotherapy (44.1\% (15/34) in left, 33.3\% (4/12) in right), abnormal p53 cases might have longer survival than normal p53 cases with left-sided colon cancers.

Otherwise, normal p53 cancers in left-sided cases should have other critical oncogene mutations and/or microsatellite instability (MSI), which are more harmful than TP53 mutations. Lorre et al. demonstrated that genetic alterations have an asymmetrical distribution (15). For example, alterations in SMAD4, PIK3CA, PTEN, and BRAF ${ }^{\mathrm{V} 600 \mathrm{E}}$ are dominantly located in right-sided cases, whereas $A P C$ and $K R A S / N R A S$ mutations exist on both sides. Since each gene alteration may have individual characteristics regarding malignancy and chemoresistance, each-sided tumors must have different characteristics and prognoses. Several researchers advocate molecular criteria for adjuvant chemotherapy. Sho and colleagues suggested that a five-gene mutation panel could be useful for choosing adjuvant chemotherapy induction (31). Park et al. reported that hypermethylation of TFAP $2 E$ is an independent prognostic factor for patients with adjuvant chemotherapy (32). These data suggest the significance of possible molecular biomarkers for the guidance of multimodal cancer treatment.

There are some limitations in the current study. First, the sample size was too small to identify statistically persuasive results. Second, we could not collect enough information about the KRAS/BRAF mutational status of surgical specimens, hence why we could not include them as candidate prognostic markers.

In summary, KIF 1A, PAX5, and VGF were identified as novel methylation markers of colon cancer. All of them were significantly hyper-methylated in cancer tissues. Frequent 
Table VII. Univariable and multivariable analyses for significant prognostic factors of disease-free survival after colon cancer resections in each side.

\begin{tabular}{|c|c|c|c|c|c|c|c|c|}
\hline \multirow[t]{3}{*}{ Covariates } & \multicolumn{4}{|c|}{ Right-sided (44 cases) } & \multicolumn{4}{|c|}{ Left-sided (73 cases) } \\
\hline & \multicolumn{2}{|c|}{ Univariable analysis } & \multicolumn{2}{|c|}{ Multivariable analysis } & \multicolumn{2}{|c|}{ Univariable analysis } & \multicolumn{2}{|c|}{ Multivariable analysis } \\
\hline & HR $(95 \% \mathrm{CI})$ & $p$-Value & HR $(95 \% \mathrm{CI})$ & $p$-Value & HR $(95 \% \mathrm{CI})$ & $p$-Value & HR $(95 \% \mathrm{CI})$ & $p$-Value \\
\hline \multicolumn{9}{|l|}{ Age group } \\
\hline$<70$ & Reference & 0.805 & & & Reference & 0.919 & & \\
\hline $70 \leq$ & $1.20(0.29-5.02)$ & & & & $0.94(0.30-2.97)$ & & & \\
\hline \multicolumn{9}{|l|}{ Gender } \\
\hline Female & Reference & 0.837 & & & Reference & 0.994 & & \\
\hline Male & $0.86(0.21-3.60)$ & & & & $1.00(0.32-3.16)$ & & & \\
\hline \multicolumn{9}{|l|}{ T stage } \\
\hline $\mathrm{T} 1-3$ & Reference & 0.019 & Reference & 0.136 & Reference & 0.058 & Reference & 0.028 \\
\hline $\mathrm{T} 4$ & $5.31(1.31-21.48)$ & & $3.00(0.71-12.71)$ & & $3.04(0.96-9.60)$ & & $3.72(1.15-12.05)$ & \\
\hline \multicolumn{9}{|l|}{$\mathrm{N}$ stage } \\
\hline No & Reference & 0.432 & & & Reference & 0.423 & & \\
\hline N1-2 & $1.78(0.42-7.44)$ & & & & $1.60(0.51-5.04)$ & & & \\
\hline \multicolumn{9}{|l|}{ Stage } \\
\hline I-II & Reference & 0.432 & & & Reference & 0.423 & & \\
\hline III & $1.78(0.42-7.44)$ & & & & $1.60(0.51-5.04)$ & & & \\
\hline \multicolumn{9}{|c|}{ Lymphatic invasion } \\
\hline Absent & Reference & 0.428 & & & Reference & 0.746 & & \\
\hline Present & $0.57(0.142-2.29)$ & & & & $1.24(0.36-4.59)$ & & & \\
\hline \multicolumn{9}{|c|}{ Venous invasion } \\
\hline Absent & Reference & 0.472 & & & Reference & 0.506 & & \\
\hline Present & $1.69(0.40-7.09)$ & & & & $1.50(0.45-4.99)$ & & & \\
\hline \multicolumn{9}{|c|}{ Adjuvant chemotherapy } \\
\hline No & Reference & 0.457 & & & Reference & 0.599 & & \\
\hline Yes & $1.69(0.42-6.77)$ & & & & $1.36(0.43-4.29)$ & & & \\
\hline \multicolumn{9}{|c|}{ Methylation frequency } \\
\hline Low & Reference & 0.060 & Reference & 0.049 & Reference & 0.967 & & \\
\hline High & $0.25(0.06-1.06)$ & & $0.23(0.05-0.99)$ & & $1.02(0.33-3.23)$ & & & \\
\hline \multicolumn{9}{|c|}{ p53 expression } \\
\hline Normal & Reference & 0.069 & Reference & 0.092 & Reference & 0.055 & Reference & 0.028 \\
\hline Abnormal & $6.99(0.86-56.88)$ & & $6.33(0.74-54.13)$ & & $0.33(0.11-1.02)$ & & $0.27(0.09-0.87)$ & \\
\hline \multicolumn{9}{|c|}{ ERCC1 expression } \\
\hline Normal & Reference & 0.278 & & & Reference & 0.798 & & \\
\hline Abnormal & $0.31(0.04-2.55)$ & & & & $0.82(0.18-3.74)$ & & & \\
\hline
\end{tabular}

HR: Hazard ratio; CI: confidence interval.

methylation of these genes was one of the significantly favorable prognostic factors of DFS for stage I-III right-sided colon cancers, but it had no association with DFS in leftsided colon cancers. Also, abnormal expression of p53 was related to shorter DFS in right-sided colon cancers but longer DFS in left-sided cases. As the molecular background of colon cancers seems to differ depending on the sidedness, treatment strategies should be considered individually.

\section{Funding}

This work was supported by Japan Society for the Promotion of Science (JSPS) KAKENHI Grant-in-Aid for Scientific Research (C) Number JP15K19850 and JP15H06281.

\section{Conflicts of Interest}

There are no conflicts of interest related to this study.

\section{Authors' Contributions}

Concept and designed research: M.H; Performed research: S.H., S.M. and H.T.; Data analysis: S.H., G.N., N.H. and M.H; Materials/reagents or analytic tools: S.H., M.H, M.Ka., C.T., D.K., S.Y., M.Ko. and M.F.; Wrote the paper: S.H., M.H., M.T., and Y.K.

\section{Acknowledgements}

The Authors would like to thank H. Nikki March, Ph.D., from Edanz Group (www.edanzediting.com/ac) for editing a draft of this manuscript. 
a. Right-sided colon cancers by methylation frequency

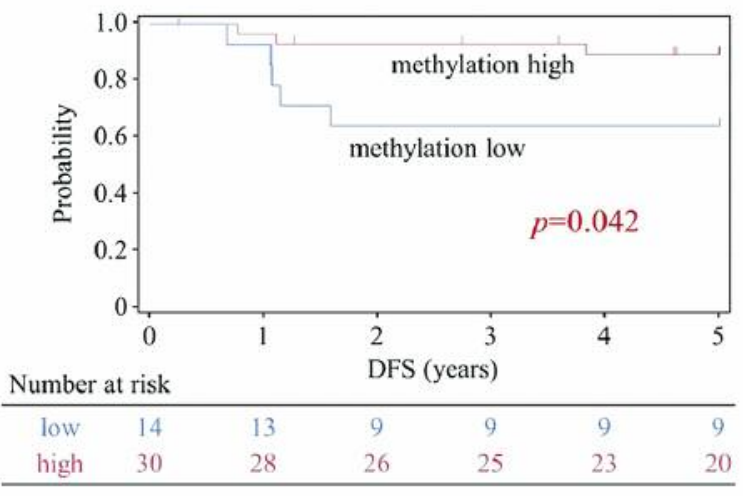

c. Right-sided colon cancers by p53 expression

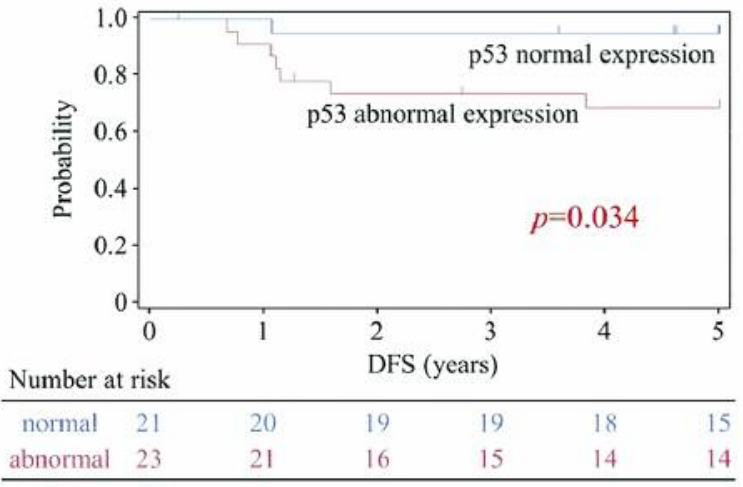

b. Left-sided colon cancers by methylation frequency

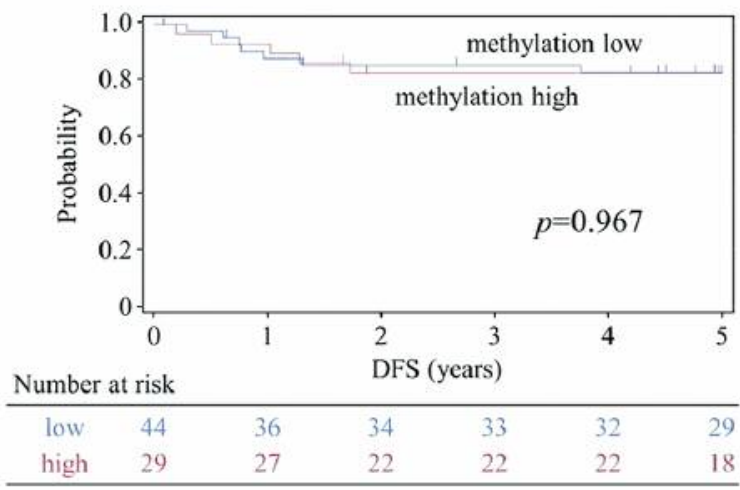

d. Left-sided colon cancers by p53 expression

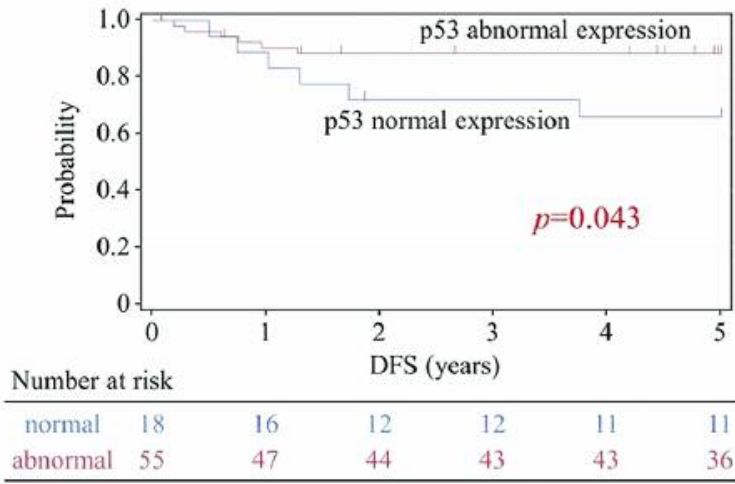

Figure 6. Survival curves of disease-free survival (DFS). The influence of methylation frequency and p53 expression on disease-free survival was examined by Kaplan-Meier curves. In right-sided colon cancers, methylation-high cases showed favorable DFS (a, $p=0.042)$. However, no difference was observed in left-sided colon cancers $(b, p=0.967)$. Abnormal expression of p53 was significantly correlated with poorer prognosis in rightsided colon cancers $(c, p=0.034)$, but with better prognosis in left-sided colon cancers $(d, p=0.043)$.

\section{References}

1 Torre LA, Bray F, Siegel RL, Ferlay J, Lortet-Tieulent J and Jemal A: Global cancer statistics, 2012. CA Cancer J Clin 65(2): 87-108, 2015. PMID: 25651787. DOI: 10.3322/caac. 21262

2 Arnold M, Sierra MS, Laversanne M, Soerjomataram I, Jemal A and Bray F: Global patterns and trends in colorectal cancer incidence and mortality. Gut 66(4): 683-691, 2017. PMID: 26818619. DOI: $10.1136 /$ gutjnl-2015-310912

3 Cross AJ, Ferrucci LM, Risch A, Graubard BI, Ward MH, Park Y, Hollenbeck AR, Schatzkin A and Sinha R: A large prospective study of meat consumption and colorectal cancer risk: An investigation of potential mechanisms underlying this association. Cancer Res 70(6): 2406-2414, 2010. PMID: 20215514. DOI: $10.1158 / 0008-5472$.can-09-3929

4 Kitahara CM, Berndt SI, de Gonzalez AB, Coleman HG, Schoen RE, Hayes RB and Huang WY: Prospective investigation of

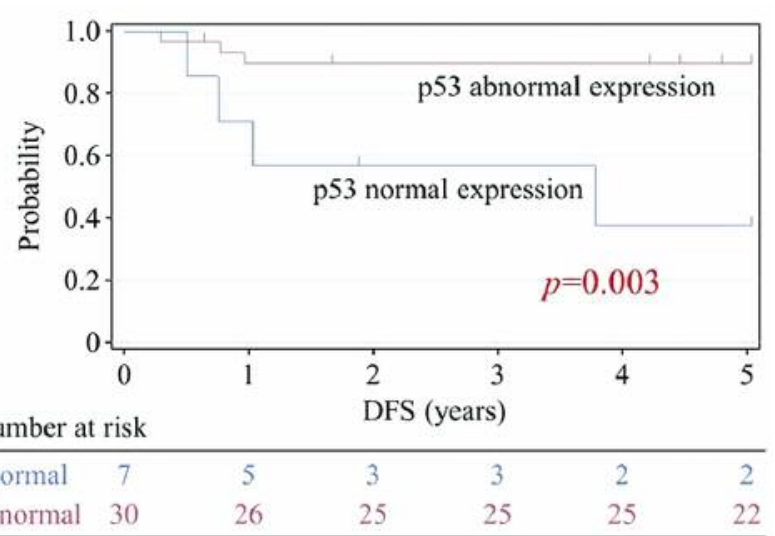

Figure 7. Survival curve of disease-free survival (DSF) in left-sided cases with adjuvant chemotherapy. Abnormal p53 cases showed longer DFS compared to normal $p 53$ cases $(p=0.003)$. 
body mass index, colorectal adenoma, and colorectal cancer in the prostate, lung, colorectal, and ovarian cancer screening trial. J Clin Oncol 31(19): 2450-2459, 2013. PMID: 23715565. DOI: 10.1200/jco.2012.48.4691

5 Svensson T, Yamaji T, Budhathoki S, Hidaka A, Iwasaki M, Sawada N, Inoue M, Sasazuki S, Shimazu T and Tsugane S: Alcohol consumption, genetic variants in the alcohol- and folate metabolic pathways and colorectal cancer risk: The JPHC study. Sci Rep 6: 36607, 2016. PMID: 27827401. DOI: 10.1038/srep36607

6 Hawkins N, Norrie M, Cheong K, Mokany E, Ku SL, Meagher A, O'Connor T and Ward R: Cpg island methylation in sporadic colorectal cancers and its relationship to microsatellite instability. Gastroenterology 122(5): 1376-1387, 2002. PMID: 11984524. DOI: $10.1053 /$ gast.2002.32997

7 Weisenberger DJ, Siegmund KD, Campan M, Young J, Long TI, Faasse MA, Kang GH, Widschwendter M, Weener D, Buchanan D, Koh H, Simms L, Barker M, Leggett B, Levine J, Kim M, French AJ, Thibodeau SN, Jass J, Haile R and Laird PW: Cpg island methylator phenotype underlies sporadic microsatellite instability and is tightly associated with braf mutation in colorectal cancer. Nat Genet 38(7): 787-793, 2006. PMID: 16804544. DOI: $10.1038 / \mathrm{ng} 1834$

8 Davies H, Bignell GR, Cox C, Stephens P, Edkins S, Clegg S, Teague J, Woffendin H, Garnett MJ, Bottomley W, Davis N, Dicks E, Ewing R, Floyd Y, Gray K, Hall S, Hawes R, Hughes J, Kosmidou V, Menzies A, Mould C, Parker A, Stevens C, Watt S, Hooper S, Wilson R, Jayatilake H, Gusterson BA, Cooper C, Shipley J, Hargrave D, Pritchard-Jones K, Maitland N, Chenevix-Trench G, Riggins GJ, Bigner DD, Palmieri G, Cossu A, Flanagan A, Nicholson A, Ho JW, Leung SY, Yuen ST, Weber BL, Seigler HF, Darrow TL, Paterson H, Marais R, Marshall CJ, Wooster R, Stratton MR and Futreal PA: Mutations of the braf gene in human cancer. Nature 417(6892): 949-954, 2002. PMID: 12068308. DOI: $10.1038 /$ nature00766

9 Ogino S, Nosho K, Kirkner GJ, Kawasaki T, Meyerhardt JA, Loda M, Giovannucci EL and Fuchs CS: Cpg island methylator phenotype, microsatellite instability, braf mutation and clinical outcome in colon cancer. Gut 58(1): 90-96, 2009. PMID: 18832519. DOI: $10.1136 /$ gut.2008.155473

10 Cohen SA, Wu C, Yu M, Gourgioti G, Wirtz R, Raptou G, Gkakou C, Kotoula V, Pentheroudakis G, Papaxoinis G, Karavasilis V, Pectasides D, Kalogeras KT, Fountzilas G and Grady WM: Evaluation of cpg island methylator phenotype as a biomarker in colorectal cancer treated with adjuvant oxaliplatin. Clin Colorectal Cancer 15(2): 164-169, 2016. PMID: 26702772. DOI: $10.1016 /$ j.clcc.2015.10.005

11 Cao DZ, Ou XL and Yu T: The association of p53 expression levels with clinicopathological features and prognosis of patients with colon cancer following surgery. Oncol Lett 13(5): 35383546, 2017. PMID: 28521456. DOI: 10.3892/ol.2017.5929

12 Wang P, Liang J, Wang Z, Hou H, Shi L and Zhou Z: The prognostic value of $\mathrm{p} 53$ positive in colorectal cancer: A retrospective cohort study. Tumour Biol 39(5): 1010428317703651, 2017. PMID: 28468582. DOI: 10.1177/1010428317703651

13 Choueiri MB, Shen JP, Gross AM, Huang JK, Ideker T and Fanta $\mathrm{P}$ : Ercc1 and ts expression as prognostic and predictive biomarkers in metastatic colon cancer. PLoS One 10(6): e0126898, 2015. PMID: 26083491. DOI: 10.1371/journal.pone.0126898

14 Mima K, Nowak JA, Qian ZR, Cao Y, Song M, Masugi Y, Shi Y, da Silva A, Gu M, Li W, Hamada T, Zhang X, Wu K,
Meyerhardt JA, Baba H, Giovannucci EL, Chan AT, Fuchs CS, Ogino S and Nishihara R: Tumor line-1 methylation level and colorectal cancer location in relation to patient survival. Oncotarget 7(34): 55098-55109, 2016. PMID: 27391152. DOI: 10.18632/oncotarget.10398

15 Loree JM, Pereira AAL, Lam M, Willauer AN, Raghav K, Dasari A, Morris VK, Advani S, Menter DG, Eng C, Shaw K, Broaddus R, Routbort MJ, Liu Y, Morris JS, Luthra R, MericBernstam F, Overman MJ, Maru D and Kopetz S: Classifying colorectal cancer by tumor location rather than sidedness highlights a continuum in mutation profiles and consensus molecular subtypes. Clin Cancer Res 24(5): 1062-1072, 2018. PMID: 29180604. DOI: 10.1158/1078-0432.ccr-17-2484

16 Hoque MO, Kim MS, Ostrow KL, Liu J, Wisman GB, Park HL, Poeta ML, Jeronimo C, Henrique R, Lendvai A, Schuuring E, Begum S, Rosenbaum E, Ongenaert M, Yamashita K, Califano J, Westra W, van der Zee AG, Van Criekinge W and Sidransky D: Genome-wide promoter analysis uncovers portions of the cancer methylome. Cancer Res 68(8): 2661-2670, 2008. PMID: 18413733. DOI: 10.1158/0008-5472.can-07-5913

17 Guerrero-Preston R, Michailidi C, Marchionni L, Pickering CR, Frederick MJ, Myers JN, Yegnasubramanian S, Hadar T, Noordhuis MG, Zizkova V, Fertig E, Agrawal N, Westra W, Koch W, Califano J, Velculescu VE and Sidransky D: Key tumor suppressor genes inactivated by "greater promoter" methylation and somatic mutations in head and neck cancer. Epigenetics 9(7): 1031-1046, 2014. PMID: 24786473. DOI: 10.4161/epi.29025

18 Hayashi M, Guerrero-Preston R, Sidransky D and Koch WM: Paired box 5 methylation detection by droplet digital pcr for ultra-sensitive deep surgical margins analysis of head and neck squamous cell carcinoma. Cancer Prev Res (Phila) 8(11): 10171026, 2015. PMID: 26304463. DOI: 10.1158/1940-6207.capr$15-0180$

19 McGregor MJ, Fadhil W, Wharton R, Yanagisawa Y, Presz M, Pritchard A, Womack C, Dutton S, Kerr RS, Kerr DJ, Johnstone EC and Ilyas M: Aberrant p53 expression lacks prognostic or predictive significance in colorectal cancer: Results from the victor trial. Anticancer Res 35(3): 1641-1645, 2015. PMID: 25750322.

20 Yamauchi M, Morikawa T, Kuchiba A, Imamura Y, Qian ZR, Nishihara R, Liao X, Waldron L, Hoshida Y, Huttenhower C, Chan AT, Giovannucci E, Fuchs $\mathrm{C}$ and Ogino S: Assessment of colorectal cancer molecular features along bowel subsites challenges the conception of distinct dichotomy of proximal versus distal colorectum. Gut 61(6): 847-854, 2012. PMID: 22427238. DOI: 10.1136/gutjnl-2011-300865

$21 \mathrm{Chu} \mathrm{CH}$, Chang SC, Wang HH, Yang SH, Lai KC and Lee TC: Prognostic values of epdr1 hypermethylation and its inhibitory function on tumor invasion in colorectal cancer. Cancers (Basel) 10(10), 2018. PMID: 30360391. DOI: 10.3390/cancers10100393

22 Inoue A, Okamoto K, Fujino Y, Nakagawa T, Muguruma N, Sannomiya K, Mitsui Y, Takaoka T, Kitamura S, Miyamoto H, Okahisa T, Fujimori T, Imoto I and Takayama T: B-raf mutation and accumulated gene methylation in aberrant crypt foci (acf), sessile serrated adenoma/polyp (ssa/p) and cancer in ssa/p. Br J Cancer 112(2): 403-412, 2015. PMID: 25314065. DOI: 10.1038/bjc. 2014.545

23 Rad R, Cadinanos J, Rad L, Varela I, Strong A, Kriegl L, Constantino-Casas F, Eser S, Hieber M, Seidler B, Price S, Fraga MF, Calvanese V, Hoffman G, Ponstingl H, Schneider G, Yusa K, 
Grove C, Schmid RM, Wang W, Vassiliou G, Kirchner T, McDermott U, Liu P, Saur D and Bradley A: A genetic progression model of braf(v600e)-induced intestinal tumorigenesis reveals targets for therapeutic intervention. Cancer Cell 24(1): 15-29, 2013. PMID: 23845441. DOI: 10.1016/j.ccr.2013.05.014

24 Chen KH, Lin YL, Liau JY, Tsai JH, Tseng LH, Lin LI, Liang JT, Lin BR, Hung JS, Chang YL, Yeh KH and Cheng AL: Braf mutation may have different prognostic implications in earlyand late-stage colorectal cancer. Med Oncol 33(5): 39, 2016. PMID: 27034263. DOI: 10.1007/s12032-016-0756-6

25 Bouzourene H, Gervaz P, Cerottini JP, Benhattar J, Chaubert P, Saraga E, Pampallona S, Bosman FT and Givel JC: P53 and kiras as prognostic factors for dukes' stage b colorectal cancer. Eur J Cancer 36(8): 1008-1015, 2000. PMID: 10885605. DOI: 10.1016/s0959-8049(00)00036-8

26 Nakayama M and Oshima M: Mutant p53 in colon cancer. J Mol Cell Biol 11(4): 267-276, 2019. PMID: 30496442. DOI: $10.1093 / j m c b / m j y 075$

27 Paluszkiewicz P, Berbec H, Pawlowska-Wakowicz B, Cybulski $\mathrm{M}$ and Paszkowska A: P53 protein accumulation in colorectal cancer tissue has prognostic value only in left-sided colon tumours. Cancer Detect Prev 28(4): 252-259, 2004. PMID: 15350628. DOI: 10.1016/j.cdp.2004.05.001

28 Adrover E, Maestro ML, Sanz-Casla MT, del Barco V, Cerdan J, Fernandez $\mathrm{C}$ and Balibrea JL: Expression of high p53 levels in colorectal cancer: A favourable prognostic factor. Br J Cancer 81(1): 122-126, 1999. PMID: 10487622. DOI: 10.1038/sj.bjc.6690660
29 Soong R, Grieu F, Robbins P, Dix B, Chen D, Parsons R, House A and Iacopetta B: P53 alterations are associated with improved prognosis in distal colonic carcinomas. Clin Cancer Res 3(8): 1405-1411, 1997. PMID: 9815825.

30 Zaanan A, Cuilliere-Dartigues P, Guilloux A, Parc Y, Louvet C, de Gramont A, Tiret E, Dumont S, Gayet B, Validire P, Fléjou J-F, Duval A and Praz F: Impact of p53 expression and microsatellite instability on stage iii colon cancer disease-free survival in patients treated by 5 -fluorouracil and leucovorin with or without oxaliplatin. Ann Oncol 21(4): 772-780, 2009. PMID: 19833818. DOI: 10.1093/annonc/mdp383

31 Sho S, Court CM, Winograd P, Russell MM and Tomlinson JS: A prognostic mutation panel for predicting cancer recurrence in stages ii and iii colorectal cancer. J Surg Oncol 116(8): 9961004, 2017. PMID: 28767131. DOI: $10.1002 /$ jso.24781

32 Park SJ, Kim SM, Hong YS, Lee JL, Kim JE, Kim KP, Hong SM, Jin DH, Kim CW, Yoon YS, Park IJ, Lim SB, Yu CS, Kim JC and Kim TW: Tfap2e methylation status and prognosis of patients with radically resected colorectal cancer. Oncology 88(2): 122-132, 2015. PMID: 25341849. DOI: 10.1159/000362820

Received December 1, 2019

Revised December 10, 2019

Accepted December 12, 2019 